\title{
AMS RADIOCARBON DATES FROM THREE SHELLMOUNDS IN THE SAN FRANCISCO BAY AREA, CALIFORNIA, USA
}

\author{
Tsim D Schneider \\ Archaeological Research Facility, University of California, 2251 College Building, Berkeley, California 94720-1076, USA. \\ Email: tsim@berkeley.edu.
}

\section{INTRODUCTION}

This paper presents a set of accelerator mass spectrometry (AMS) radiocarbon dates obtained from various archaeological samples collected from 3 shellmounds-CA-MRN-114, CA-MRN-115, and CA-MRN-328 - within China Camp State Park, Marin County, California, USA.

Nelson (1907) recorded "Shellmound No. 114" (CA-MRN-114) and "Shellmound No. 115" (CAMRN-115) as part of an archaeological survey in the early 1900s. Nelson mapped both shellmounds and their associated features, including multiple pit features on the top of CA-MRN-115. CA-MRN328 was identified after the creation of China Camp State Park in the 1970s. Subsequent archaeological research at CA-MRN-115 was conducted in 1949 by Clement W Meighan, who supervised excavations of twelve $5 \times 5$ foot units located at the south end of the site; 5 auger units; and 1 pit feature ("House-pit 7") on top of the mound (Meighan 1953). In addition to faunal remains, a shell ornament, and lithic artifacts, excavation within House-pit 7 yielded burned wood house planks, grass thatching, and the nested remains of 4 plain and diagonal twined baskets.

As part of Meighan's analysis of the CA-MRN-115 assemblage, 2 organic samples (sample C-186; Libby 1955:112) were submitted for ${ }^{14} \mathrm{C}$ dating. A larger sample size requirement for ${ }^{14} \mathrm{C}$ samples in the 1950s necessitated selection of multiple carbon samples from various depths at CA-MRN115: 108 inches $(2.7 \mathrm{~m})$ and $114-132$ inches (2.9-3.4 m) below surface (Meighan 1953:6). The ${ }^{14} \mathrm{C}$ values for these samples are $633 \pm 200$ and $911 \pm 80 \mathrm{BP}$ (Libby 1955:112), which were also averaged to produce a mean ${ }^{14} \mathrm{C}$ value of $720 \pm 130 \mathrm{BP}$ (Meighan 1953:5), or cal AD 1035-1432 (2 $\sigma$ ) using the OxCal 4.0 calibration program (Bronk Ramsey 2009). Accordingly, CA-MRN-115 contains, at minimum, a Middle-Late Period Transition component (AD 700-1100). A foot of soil deposited on top of the excavated house pit, the shell ornament, and a notched obsidian projectile point recovered near the surface of CA-MRN-115 led Meighan to conclude that the site was abandoned by AD 1800 (Meighan 1953:4-5), and that "the occupants of this village were taken to one of the Spanish missions" (Meighan 1953:5).

My archaeological fieldwork at CA-MRN-114, CA-MRN-115, and CA-MRN-328 took place between 2007 and 2008 and addresses long-term use and reuse of these sites by hunter-gatherers before, during, and after Spanish settlement in the San Francisco Bay area (AD 1776 to the 1830s) (Schneider 2010). Despite a detailed prehistoric archaeological record at many Bay Area shellmound sites, knowledge of hunter-gatherer shellmound use at contact is limited. To this end, AMS ${ }^{14} \mathrm{C}$ data were collected to further elucidate the timing of shellmound residence during the Late Period (AD 900-1800) and, especially, into historic times.

\section{ACKNOWLEDGMENTS}

I thank the Federated Indians of Graton Rancheria and their Sacred Sites Protection Committee; the California Department of Parks and Recreation; Madeleine Fang, Natasha Johnson, and Joan Knudsen at the Phoebe A Hearst Museum of Anthropology; and colleagues and student volunteers who assisted at various stages of my research. Funding for AMS ${ }^{14} \mathrm{C}$ dates was made possible by James Allen and the William Self Associates Fellowship. 


\section{ARCHAEOLOGICAL SAMPLES}

\section{CA-MRN-114 (China Camp State Park, Marin County, California)}

Beta-254226

$380 \pm 40 \mathrm{BP}$

CCAPMRN11401

$\delta^{13} \mathrm{C}=-\mathbf{2 4 . 7 \%}$

Carbonized wood $(0.26 \mathrm{~g})$ handpicked from the basin of a stone-lined hearth feature ("Feature 1"). CA-MRN-114, Unit 1078N/1056E, Stratum 4a, 40-45 cm below ground surface. China Camp State Park is in Marin County, California, $\sim 6.5 \mathrm{~km}$ northeast of San Rafael, California, USA (37 $58^{\prime} 24^{\prime \prime} \mathrm{N}$, $\left.122^{\circ} 31^{\prime} 52^{\prime \prime} \mathrm{W}\right)$.

Comment: This sample produced a conventional ${ }^{14} \mathrm{C}$ age of $380 \pm 40 \mathrm{BP}$, or cal AD 1440-1640 (2 $\left.\sigma\right)$ (510-310 cal BP; 2- $\sigma$ calibration following Vogel et al. [1993]).

\section{Beta-254227}

$640 \pm 40 \mathrm{BP}$

CCAPMRN11402

$\delta^{13} \mathrm{C}=-1.7 \%$

Fossilized shell—bay mussel (Mytilus edulis) fragments totaling $1.61 \mathrm{~g}$ - handpicked from the basin of a stone-lined hearth feature ("Feature 1"). CA-MRN-114, Unit 1078N/1056E, Stratum 4a, 40-45 $\mathrm{cm}$ below ground surface, China Camp State Park.

Comment: This sample produced a conventional ${ }^{14} \mathrm{C}$ age of $1020 \pm 40 \mathrm{BP}$, or cal AD 1480-1680 $(2 \sigma)(470-270$ cal BP; 2- $\sigma$ calibration following Vogel et al. [1993]). To calibrate all marine shellfish samples, a carbon reservoir, $\Delta \mathrm{R}$, value of $300 \pm 35$ for San Pablo Bay was applied and calculated by averaging known $\Delta \mathrm{R}$ values for the San Pablo Bay (Ingram and Southon 1996). Both samples collected from "Feature 1" imply that this feature is Late Period Phase 1 (AD 900-1500) and Late Period Phase 2 (AD 1500-1800) in age.

Beta-254228

$510 \pm 40 \mathrm{BP}$

CCAPMRN11403

$\delta^{13} \mathrm{C}=-3.1 \%$

Fossilized shell-bay mussel (Mytilus edulis) umbos totaling $0.79 \mathrm{~g}$-collected $20-40 \mathrm{~cm}$ below ground surface in an excavated auger unit (AU1083N/1055E) at CA-MRN-114, China Camp State Park.

Comment: This sample produced a conventional ${ }^{14} \mathrm{C}$ age of $870 \pm 40 \mathrm{BP}$, or cal AD $1650-1880(2 \sigma)$ (300-70 cal BP; 2- $\sigma$ calibration following Vogel et al. [1993]). The sample was calibrated using a carbon reservoir, $\Delta \mathrm{R}$, value of $300 \pm 35$ for San Pablo Bay. In addition to a Late Period Phase 2 component, this date indicates MRN-114 also contains stratigraphic deposits dating to historical times. Temporally diagnostic projectile point types and shell artifacts excavated from the 3 shellmounds corroborate ${ }^{14} \mathrm{C}$ data and imply historic residence (Schneider 2010).

Beta-254229

$1520 \pm 40 \mathrm{BP}$

CCAPMRN11404

$\delta^{13} \mathrm{C}=-3.5 \%$

Fossilized shell-bay mussel (Mytilus edulis) umbos totaling $0.77 \mathrm{~g}$-collected 80-100 cm below ground surface in an excavated auger unit (AU1083N/1055E) at CA-MRN-114, China Camp State Park.

Comment: This sample produced a conventional ${ }^{14} \mathrm{C}$ age of $1870 \pm 40 \mathrm{BP}$, or cal AD 700-940 (2 $\left.\sigma\right)$ (1240-1010 cal BP; 2- $\sigma$ calibration following Vogel et al. [1993]). The sample was calibrated using a carbon reservoir, $\Delta \mathrm{R}$, value of $300 \pm 35$ for San Pablo Bay. The deepest ${ }^{14} \mathrm{C}$ sample collected from MRN-114, this date implies some of the earliest shell layers were deposited during the Middle-Late Period Transition (AD 700-1100) and has implications for considering contemporaneous occupation at MRN-114 and MRN-115. 


\section{CA-MRN-115, the Thomas Site (China Camp State Park, Marin County, California)}

Beta-250547

$\begin{aligned} \text { CCAPMRN11501 } & \delta^{13} \mathbf{C}=-\mathbf{2 5 . 3 \%}\end{aligned}$

$280 \pm 40 \mathrm{BP}$ the floor of a house depression ("House-pit 7") on top of CA-MRN-115 (the Thomas site) Chin Camp State Park, which is $\sim 6.5 \mathrm{~km}$ northeast of San Rafael, California, USA $\left(37^{\circ} 58^{\prime} 24^{\prime \prime} \mathrm{N}\right.$, $\left.122^{\circ} 31^{\prime} 52^{\prime \prime} \mathrm{W}\right)$. The basketry remains were collected at a depth of 14 inches $(35.5 \mathrm{~cm})$ by Clement Meighan in 1949 (Meighan 1953:2), and then archived at the Lowie Museum of Anthropology (now the Phoebe A Hearst Museum of Anthropology), University of California, Berkeley. T D Schneider collected and submitted the ${ }^{14} \mathrm{C}$ sample (Schneider 2010).

Comment: As described by Meighan (1953:3), the remains of burned baskets were found "30 inches west of the hearth... [and were] preserved in a carbonized form but... in poor condition, having been crumpled by a collapsing house timber which lay on top of the fragments." It is possible that archival adhesives and chemical preservatives were subsequently applied to organic remains in the MRN-115 collection. To obtain appropriate samples from the museum specimens, larger samples were collected for chemical pretreatment. A 251-mg sample was snipped from a basket fragment and underwent solvent extraction at Beta Analytic Inc. (Miami, Florida, USA), which ultimately yielded a 3.7 -mg carbon sample. The conventional ${ }^{14} \mathrm{C}$ age for this sample is $280 \pm 40 \mathrm{BP}$, with 2 possible calibrated age ranges of cal AD 1490-1670 and cal AD 1780-1790 (2 б) (460-280 and $160-160$ cal BP, respectively; 2- $\sigma$ calibration following Vogel et al. [1993]). The date confirms site residence during the Late Period Phase 2 (AD 1500-1800) and, considering the ${ }^{14} \mathrm{C}$ dates reported by Meighan (1953:5), at minimum a thousand-year record of human habitation at MRN-115.

\section{Beta-250548 \\ CCAPMRN11502}

$210 \pm 40 \mathrm{BP}$

$\delta^{13} \mathrm{C}=-22.2 \%$

Carbonized wood fragment weighing $226 \mathrm{mg}$. In 1949, Meighan excavated a house depression on top of the Thomas site, or CA-MRN-115 (Meighan 1953), China Camp State Park. This ${ }^{14} \mathrm{C}$ sample - possibly redwood (Sequoia sempervirens) or oak (Quercus spp.) — was part of a bark plank that once formed the wall of a conical bark house constructed on top of the shellmound. The plank was collected from "Unit 1 West" of "House-pit 7" at a depth of 12-18 inches (30-46 cm), and archived at the Lowie Museum of Anthropology (now the Phoebe A Hearst Museum of Anthropology), University of California, Berkeley. T D Schneider collected and submitted the ${ }^{14} \mathrm{C}$ sample (Schneider 2010).

Comment: Similar to the basket fragment, fragments of wood collected from MRN-115 were likely contaminated by adhesives and preservatives at the museum and required chemical pretreatment. A 226-mg chunk of carbonized wood underwent solvent extraction at Beta Analytic Inc. and ultimately produced a $2.5-\mathrm{mg}$ sample. The conventional ${ }^{14} \mathrm{C}$ age for this sample is $260 \pm 40 \mathrm{BP}$, with 4 possible calibrated age ranges of cal AD 1520-1590, 1620-1670, 1770-1800, and 1940-1950 (2 $\sigma$ ) (430-360, 330-280, 180-150, and 10-0 cal BP, respectively; $2-\sigma$ calibration following Vogel et al. [1993]). The date implies the house pit is Late Period Phase 2 in age, and is corroborated by the date produced from the basket fragment. With regard to potential chronological issues related to the recycling of old wood (Schiffer 1986), the temperate climate of the San Francisco Bay probably forced hunter-gatherers to replace rotted bark slabs every $20 \mathrm{yr}$, if not earlier (Highley 1995:412; Morrell et al. 1999; Trieu Gahr 2006:72), and the wood remains are considered reliable sources of chronometric data. 


\section{CA-MRN-328 (China Camp State Park, Marin County, California)}

\section{Beta-254230 \\ CCAPMRN32801}

$$
\begin{array}{r}
580 \pm 40 \text { BP } \\
\delta^{13} \mathrm{C}=-2.8 \%
\end{array}
$$

Fossilized shell-bay mussel (Mytilus edulis) umbos totaling $0.80 \mathrm{~g}$-collected $20-40 \mathrm{~cm}$ below ground surface in an excavated auger unit (AU969N/989E) at CA-MRN-328, China Camp State Park, which is $\sim 6.5 \mathrm{~km}$ northeast of San Rafael, California, USA $\left(37^{\circ} 58^{\prime} 24^{\prime \prime} \mathrm{N}, 122^{\circ} 31^{\prime} 52^{\prime \prime} \mathrm{W}\right)$.

Comment: This sample produced a conventional ${ }^{14} \mathrm{C}$ age of $940 \pm 40 \mathrm{BP}$, or cal AD 1540-1720, $1740-1750$, and $1790-1800$ (410-220, 210-200, and 160-150 cal BP; $2-\sigma$ calibration following Vogel et al. [1993]). The sample was calibrated using a carbon reservoir, $\Delta \mathrm{R}$, value of $300 \pm 35$ for San Pablo Bay.

\section{Beta-254231}

$460 \pm 40 \mathrm{BP}$

CCAPMRN32802

Fossilized shell—bay mussel (Mytilus edulis) umbos totaling $0.65 \mathrm{~g}$-collected 120-140 cm below ground surface in an excavated auger unit (AU969N/989E) at CA-MRN-328, China Camp State Park.

Comment: This sample produced a conventional ${ }^{14} \mathrm{C}$ age of $870 \pm 40 \mathrm{BP}$, or cal AD 1650-1880 (2 $\left.\sigma\right)$ (300-70 cal BP; 2- $\sigma$ calibration following Vogel et al. [1993]). The sample was calibrated using a carbon reservoir, $\Delta \mathrm{R}$, value of $300 \pm 35$ for San Pablo Bay. The 2 dates from MRN-328 imply that the site is Late Period Phase 2 (AD 1500-1800) in age. However, since $1 \mathrm{~m}$ depth separates the stratigraphic deposits from which the 2 shell samples were collected, it is possible that MRN-328 was impacted by taphonomic disturbances, including rodent burrowing, historic-era ranching activity, and other landscape modifications such as the adjacent construction of a cement cistern used for watering livestock (Brienes 1983).

\section{REFERENCES}

Brienes M.1983. China Camp and the San Francisco Bay Shrimp Fishery. Sacramento: Office of Interpretive Services, California Department of Parks and Recreation. 162 p.

Bronk Ramsey C. 2009. Bayesian analysis of radiocarbon dates. Radiocarbon 51(1):337-60.

Highley TL. 1995. Comparative durability of untreated wood in use above ground. International Biodeterioration and Biodegradation 35(4):409-19.

Ingram BL, Southon JR. 1996. Reservoir ages in eastern Pacific coastal and estuarine waters. Radiocarbon 38(3):573-82.

Libby WF. 1955. Radiocarbon Dating. 2nd edition. Chicago: University of Chicago Press. 175 p.

Meighan CW. 1953. Preliminary excavations at the Thomas Site, Marin County. Reports of the University of California Archaeological Survey 19:1-14. Berkeley: University of California.

Morrell JJ, Miller DJ, Schneider PF. 1999. Service Life of Treated and Untreated Fence Posts: 1996 Post Farm Report. Research Contribution 26, Forest Research
Laboratory, Oregon State University. 24 p.

Nelson NC. 1907. San Francisco Bay Mounds. University of California Archaeological Survey Manuscripts 349. Berkeley: Phoebe A Hearst Museum of Anthropology, University of California.

Schiffer MB. 1986. Radiocarbon dating and the "old wood" problem: the case of the Hohokam chronology. Journal of Archaeological Science 13(1):13-30.

Schneider TD. 2010. Placing refuge: shell mounds and the archaeology of colonial encounters in the San Francisco Bay Area, California [PhD dissertation]. Berkeley: University of California. $281 \mathrm{p}$.

Trieu Gahr DA. 2006. From architects to ancestors: the life cycle of plank houses. In: Sobel E, Trieu Gahr DA, Ames KM, editors. Household Archaeology on the Northwest Coast. International Monographs in Prehistory, Archaeological Series 16. Ann Arbor: International Monographs in Prehistory. p 57-79.

Vogel JC, Fuls A, Visser E, Becker B. 1993. Pretoria calibration curve for short-lived samples, 1930-3350 BC. Radiocarbon 35(1):73-85. 